\title{
Increasing the Brand Awareness of SUAPI of PT. Garuda Top Plasindo by Highlighting its Unique Selling Points in a Promotional Video
}

\author{
Jenet katili \\ English Department, Faculty of Languages and Literature, Petra Christian University \\ Siwalankerto 121-131, Surabaya 60236, East Java, INDONESIA \\ E-mail: einkatili96@gmail.com
}

\begin{abstract}
PT. Garuda Top Plasindo is a family business that was established in 2001. It is located at Rungkut Industri III/17, Surabaya. Its main product is SUAPI. SUAPI is a brand of its disposable cutleries such as spoons, forks, knives, drinking cups, chopsticks, and many more. As a big company, PT. Garuda Top Plasindo also has some competitors, two of which are Cicipi and Victory. Those two brands also sell disposable cutleries but with a lower price. Because of that, the company has a problem related to the price. The company has lost some of its distributors because they prefer to buy cheap products from those two other brands. However, SUAPI has some uniqueness that the others do not have. The first is safe. The company uses food-grade material to produce the cutleries. Using safety cutleries is important that we can be spared from chemical material that can cause illness. The second is variety. SUAPI has various designs and colors that will make your party more colorful. Therefore, the solution of the problem is emphasizing the two selling points in a promotional video to increase the brand awareness. It is a good solution for the company because they will have a new tool that can help them in explaining the USP of SUAPI to the customers. This tool will show the uniqueness of SUAPI that the other brands do not have. There are several benefits that the company will get from this project. First, many customers and prospects will know about the uniqueness of SUAPI. Second, the company will find it easier to promote the products to the target markets.
\end{abstract}

Keywords: brand awareness, unique selling points, promotional video.

\section{INTRODUCTION}

PT. Garuda Top Plasindo is a family business that was established in 2001. It is located at Rungkut Industri III/17, Surabaya. The company uses a number of most modern Japanese injectionmolding-machineries, along with the application of fully robotic assembling systems to support the production. Their first products were GT-PRO videocassettes and CD protective cases that had successfully distributed to many major cities in Indonesia and also overseas. This success has led the company to be more successful in developing its business. In 2011, PT. Garuda Top Plasindo proudly launched its new product named SUAPI. SUAPI is a brand of its disposable cutleries such as spoon, fork, knife, drinking cup, and many more. Those products have been distributed to many major cities in Indonesia and there are so many distributors who have cooperated with the company. Because there are more than a hundred distributors from around a hundred cities in Indonesia have been cooperating with this company, now, PT. Garuda Top Plasindo is trying to export those products to some countries such as Singapore, Malaysia, Philippine, Australia, and many more.

During my 3-month internship in PT. Garuda Top Plasindo, I could find some brands of competitors such as Cicipi and Victory. Some distributors of SUAPI also buy those brands. However, SUAPI has some uniqueness that the other brands do not have. First, SUAPI products are stronger than the others. Second, SUAPI has many variants of colors for spoon and fork. The colors are red, orange, yellow, green, blue, indigo, violet, and black. Second, SUAPI has more variant of products than the competitors have. Besides of spoon and fork, SUAPI also has other variants such as disposable knife, chopstick, brush toothpick, drinking cup, and logo spoon that will fulfill people's needs. Then, while I was doing my internship I could also find some problems related to the Marketing process. 


\section{PRINCIPLES FOR DESIGNING NEW PRODUCTS}

From the problem, I decided to make a promotional video which focuses on the USP of the products. In this chapter, to make and finish this project completely, I use some information from textbook to understand about the definition, purposes, and features used in making a promotional tool for a company.

\section{Branding}

A brand is a promise of satisfaction; it means that every brand should have a characteristic that can be remembered by the customers. A brand needs a good name because by creating a good name, it will bring a good reputation for the brand itself. (Healey, 2008, p. 6-10) While, Branding is a process to ensure the success of a product or service by making people trust that the product or service is better than the other. Branding can reinforce a good reputation, encourage loyalty, assure quality, and convey a perception of greater worth (allowing a product to be priced higher). Branding is a two-way process between the producers and customers. (Healey, 2008, p. 10-14, 26-28) By branding, a company can set the customers' mindset about its product. Branding can give a good reputation for a product even though the quality is more or less the same as the competitor. Doing branding is very important to stand out companies products because there will be many competitors who will make the same products but at the lower prices. Therefore, branding will help creating a good image of a product and make customers easily recognize the brand. (Healey, 2008, p. 10-11)

\section{Promotion}

Promotion is a communication process of marketers to market targets in order to explain about a product or service and to persuade the target markets to take a buying action. (Kalb, 2002, p. 181-191) There are three types of promotion that are most often done. First is through Web page design and online advertising. By using online advertising, companies let the target markets know that they exist, and through online advertising they can lead them to visit their Web site page. Second is through Broadcast media. If there are big companies who sell products in a great number, they can use broadcast media such as television and radio to promote their products because it can reach as many people. Third is through video. This promotion method can be more effective in promoting products because they can be shown in action as the video explains their benefits and advantages over the competitors. (Kalb, 2002, p. 181-191)

\section{Promotional Tool}

Promotional tools are advertising, publicity, and sales promotion. Companies use those media to promote their products to the customers. A promotional tool will inform the customers about the existence of the products and develop brand awareness. Promoting products by using a tool should be combined with a selling skill. (MacKenzie, 2002, p. 60-62) There are five promotional tools used by companies to reach customers. First is traditional media, which means companies create an advertisement and publish it through television networks, radio stations, newspapers, and magazines. They will also use support media in ongoing campaigns, such as billboards, directories, buses, aerial and point-of-purchase displays. This method tends to be most affordable for smaller companies. Second is digital technology, which means companies can use mobile devices with applications for electronic communication and social media to reach many customers directly because it will make them easier to promote the products wherever they go. Third is public relations tools, which means companies can use press releases, newsletters, press conferences and news reports to promote their products to customers because those promotional tools is used specifically to public relations. It can directly reach many people and also build the good name of company. Fourth is events, which means by sponsoring major events and community activities, it will give big opportunities for companies to promote their products. A presence at local fairs and non-profit events can build the relation between companies and their customers. The last is salespeople and influencers, which means salespeople and influencers are the more direct promotional tools. They will ask questions, listen to customer needs and use persuasive efforts to sell product or service benefits. (Kokemuller, 2018) 


\section{Promotional Video}

Promotional video is a piece of content specifically designed to promote the company's products and services to customers and prospects. The main goal is to give the audience a feel for their brands and what their businesses are about. However, a promotional video should not more than two minutes because people tend to bored watching a long promotional video. (Klass, 2018)

There are several steps in making a good promotional video. The first step is identifying their goals. Before making the script of their video, they need to consider why they should create a video because the cost of a promotional video is high so it is important to know what their goals are. The more goals they put into one video, the more they will complicate the script and confuse their audiences, so think carefully about what they want to achieve from their video.

The second step is choosing a direction. To give they some ideas, there are list of possible directions they could go in. First is introductory, which means telling their audience who they are, explain their mission, etc. Second is explanatory, which means explaining how something works (like their products or specific features). Third is problem/solution, means showing the old way/new way and how their product is the solution. Fourth is narrative, which means using story elements (like plot, conflict, resolution, etc) to subtly introduce or explain something. Fifth is drive action, which means getting the audience to do something (i.e. shop now). Sixth is product-focused, which means introducing or showcasing a specific product or feature. Seventh is testimonial, which means interviewing, quoting, etc, with customers around a specific topic or theme. Eighth is endorsement, which means using of celebrity or influencer approval/likeness. Ninth is informative, which means educating their audience about something specific, tutorial-style, etc. Tenth is entertainment, which means delighting or inspiring their audience using story, humor, etc.

The third step is setting the tone. Think about what their audience will feel when watching their video. The creative direction they choose should play well with the tone they choose. Some various tones they can explore for their concept and creative direction. Dramatic- moves them emotionally. Straightforward/informative means clear and concise. Conversational means casual and authentic. Urgent- urges them to take action, like now. Fun/playful means using fun creative devices (like anthropomorphism, for example). Humorous- comedic makes them laugh or smile. Quirky- uses peculiarity or the unexpected to drive home a point. Cutesy - something that makes them go. Entertaining-aims to inform and entertain. Inspirational means using inspiration to drive action (manifestos are typically done in this style). Artsy /hip/cool-feels youthful, stylish, trendy, etc. Luxurious-shiny, fancy, flashy, sexy, rich.

The fourth step is deciding on duration. They need to consider their goals, where the ad will appear and the overall budget to decide how long their video will take time. The fifth step is choosing a video style. They need to decide what their video will look like. It can be animated or live action, etc. The sixth step is outlining the idea. They need to think about the scenes, characters, audio/voice over/ text overlay, product, props, and the final CTA, means what is the last message we leave the audience with?. The seventh step is writing the script. The main things they need to have in their layouts are the scene number, the time stamp, the audio, dialogue, or voice over, and a description of the scene, list of characters, locations, special props, expressions or movements, or any other details. The last step is storyboard. Storyboard is a guide for them, their videographer, and their actors/actress to know what they need to do in the video. They have to write the storyboard in detail so that they will not get confused with the acting. (Maguire, 2016)

\section{Usp (Unique Selling Point)}

USP is a crucial element that makes their product different from the competitors. (Stone, 2001, p.27-29) Unique selling point will help them stand out from their competitors. It is important to tell their customers about their USP because it will help them easily remember their products and identify their products between the competitors. (Kettle, 2017) There are six points that can help companies to identify their USP. The first one is they have to know what they stand for, what their purpose is, and why. The second one is they need to identify who their ideal target market is. The third one is who else works in this space. The fourth one is what makes them different from their competitors and what they offer that others do not. To help them identify it, they can ask their customers why they choose their products than their competitors. The fifth one is they need to know 
what people say when talking about their products. And the last one is they need to make a survey about what the real reasons people buy their products. (Kettle, 2017)

\section{THE COMPANY'S PROBLEM AND ITS SOLUTION}

\section{The Problem}

The problem that I found is the company has lost some of its distributors because of the price competition. There are two brand competitors that sell disposable cutleries but with a lower price, they are Cicipi and Victory. Some of SUAPI's distributors said that they could get cheaper price from the competitors that was why they stopped to order SUAPI. The distributors only focus on getting lower price rather than selling good products. It is true that SUAPI's price is more expensive than other brands, but SUAPI products have some uniqueness that others do not have. In this case, there are many customers and prospects that need to know about the quality of SUAPI. They should understand why SUAPI is more expansive than others. However, the company does not have any tools that can help them to deliver the messages to the customers that makes the customers do not have access to know more about SUAPI. The company needs an effective tool that can promote the products to many customers as well as increase the brand awareness of SUAPI. I think, the company should have a tool that can reach as many people in all areas in order to increase the sales. In this case, a promotional video could be an effective tool that can reach a lot of people to see and know more about SUAPI products because it will be shared through some social media. Until present, the company also does not have any appropriate tool to help them promoting SUAPI.

\section{The Solution}

For the concept of the promotional video, I choose two uniqueness to be shown in the video. But before explaining the uniqueness, I start with a short drama that leads into the next scene. At the beginning, there are two women; one is an owner of a catering business and another is a housewife who wants to order catering for her daughter's birthday party. Then, the housewife calls the owner catering to order the catering but she has a special request to the owner. She asks the owner to use disposable cutleries which are safe, various in colors and designs. Because of the main guests of the party are children, she is worried if the disposable cutleries are not safe to use. Then, the theme of the party is colorful so she request to use colorful disposable cutleries. The last, she wants to use spoons that can be put stickers of happy birthday in the handle, so that the atmosphere can be more cheerful. The first time the catering owner says that she cannot provide that kind of disposable cutleries because she does not know where to find them. Then the customer compels her to provide it because she will place her order in large quantities. Because she does not want to lose her customer, the owner catering say that she will provide the request. After she hangs up, she looks very confused and suddenly SUAPI comes as the answer of her problem.

The next scene is the solution for the catering owner's problem. SUAPI is a brand of disposable cutleries which are safe and has many variant in colors and designs. The first USP is safe. In this scene, I explain that SUAPI uses good raw material (foodgrade) which is safe to be used for people especially children, and the company has already got ISO certificate in food safety. The scene shows the raw material and the clean activities in the factory. The second USP is various. In this scene, I show all the variant colors and designs putting in a sweet corner. The sweet corner is the representation of the birthday party of the customer's daughter. It shows the application of the products.

The messages of the video is to tell the customers and prospects that SUAPI is a brand of disposable cutleries that sells guaranteed safe products and has many variant in colors and designs that will fulfill their needs. This tool is for all the customers and prospects of SUAPI, especially for food sellers. By using good disposable cutleries, they can increase the good image of their businesses because a good business can be identified from the tools that they use. If you use good quality tools for your business, it means that you give the best for your customers. I create that scenario because I want to emphasize that people need safe plastic cutleries which made from good raw material and are free from chemical material, and sometimes there are some customers who have several request for the cutleries to the food sellers especially catering, in which only SUAPI can answer their needs. 
Then, this tool will be used on social media because social media can reach many people to watch. It will be put on Youtube and Instagram which are the most popular social media that have many users. The time of the video is one minute and twenty one seconds. I make it short because I think people will get bored to see a long video promotion on Youtube channel and they will just skip the promotion if it takes a long time. In my opinion, a short video promotion can easily catch people attention rather than a long video. The video will also be put on Instagram. Even if the maximum duration of a video on Instagram is only one minute, we can still upload a video more than one minute because Instagram can show the whole video by dividing it into several slides, so we can continue the video by swiping left. I also use Indonesian language because the video will be mostly used to get customers in local area. However, I use English to explain the USP in case the company will use the video on an exhibition, so that foreigners can understand what the uniqueness of SUAPI.

\section{The Rationale}

I believe that it is a right tool to help the company for increasing the brand awareness of SUAPI because the video shows the main USP of SUAPI that the other competing brands do not have. It will emphasize that SUAPI has a more expensive price because it gives a good quality of products. SUAPI is safe because it uses good raw material (foodgrade) in producing the products and the company has already got ISO certificate which is a guarantee that this company is consistent in producing high quality products. SUAPI also has many variant in colors and designs that the other brands do not have. SUAPI has RAINBOW series for the spoon, fork, tea spoon, logo spoon, etc. It also has many variant in designs such as spoon, fork, knife, glass, chopstick, toothpick, logo spoon, tea spoon, and many more.

This tool will be effective to solve the company's current problem because it will help the salespersons in explaining and promoting SUAPI to the customers and prospect. The video highlights the two main USP of SUAPI that the other brands do not have. Currently, the company does not have a tool that can help them to reach many customers and to highlight the USP of SUAPI. This tool will help them to increase the brand awareness of SUAPI and will be useful for the future.

\section{CONCLUSION}

The company has a problem related to the price. The company has lost some of its distributors because they prefer to buy cheap products from those two other brands, which are Cicipi and Victory. However, SUAPI has some uniqueness that the others do not have. The first is safety. The company uses food-grade material to produce the cutleries. The second is variety. SUAPI has various designs and colors. Therefore, the solution of the problem is to emphasize the two selling points in a promotional video to increase the brand awareness. The first thing that I do to start the project is making an interview with some distributors to get their opinion about the products and identify the USP. After get a clear opinion about the uniqueness, I discuss it with my advisor. Then, I start making the concept of the video and discuss it with my videographer. After we have created the concept, I come to the company to discuss about the concept as well as the price to cover the cost of making the promotional video. When the company says they agree with my project, I arrange the schedule of the shooting. Then, after the promotional video finish, I show it to my advisor to get his opinion about that.

However I get some revises related to the concept that makes me have to rearrange a schedule to retake the new video then discuss it again with my advisor. Fortunately, I can finish this promotional video and give it to the company. The company may get the best use of the tool by putting it on some social media such as Youtube, Instagram, etc, because many people like to watch videos on those social media. The company can also share the video only by using gadgets to the customers and prospects. This promotional video is the simple and effective way to promote SUAPI. 


\section{REFERENCES}

Maguire, A. (2016). 8 Steps To Creating a Promotional Video. Retrieved December 03, 2018, from https://medium.com/swlh/how-to-create-a-promotional-video-707fa7a63019

MacKenzie, I. (2002). English for Business Studies: A course for Business Studies and Economics Students. United Kingdom: Cambridge University Press.

Kalb, I.S. (2002). e-Marketing: What went wrong and how to do it right. California: K\&A Press.

Healey, M. (2008). What is Branding?.Singapore: Page One Publishing Pte Ltd.

Kettle, M. (2017). The Importance of Having a Unique Selling Point (USP). Retrieved December 03, 2018, from https://www.melkettle.com/2017/05/importance-unique-selling-point/

Kokemuller, N. (2018). Marketing Promotional Tools. Retrieved December 03, 2018, from https://smallbusiness.chron.com/marketing-promotional-tools-60473.html

Stone, P. (2001). Make Marketing Work for You : Boost Your Profits with Proven Marketing Techniques. United Kingdom : How To Books.

Klass, Y. (2018). Learn What A Promotional Video Definition Is and Why It's Important. Retrieved December 03, 2018, from https://slide.ly/promo/blog/learn-what-a-promotional-videodefinition-is-and-why-its-important/ 